Polszakiewicz B., Elżbieta Mączyńska, Piotr Pysz (eds.), Ordoliberalizm i spoteczna gospodarka rynkowa wobec wyzwań wspótczesności, „Ekonomia i Prawo. Economics and Law”, Polszakiewicz B., Boehlke J. (ed.), Vol. 14, No. 2/2015, pp. 275-278. DOI: http://dx.doi.org/10.12775/ EiP.2015.017.

\title{
ELŻBIETA MĄCZYŃSKA, PIOTR PYSZ (EDS.), ORDOLIBERALIZM I SPOŁECZNA GOSPODARKA RYNKOWA WOBEC WYZWAŃ WSPÓŁCZESNOŚCI POLSKIE TOWARZYSTWO EKONOMICZNE,
} WARSZAWA 2013

The reviewed book is yet another publication on the Polish market dealing with the confrontation of German ordoliberal theory and problems of today's market economy. The fact that the socio-economic system in Poland is characterised by a sustained regression in the construction of the rule of law, gives this publication additional weight.

The formation of the theory and practical business experience have always remained in a mutual relationship. The way we perceive sets of phenomena, relationships between them and the mechanisms triggering certain processes and conditions in the economy, depends largely on theory. On the other hand, whether a given theoretical concept of economic policy becomes the foundation of its implementation is a matter not only of "quality" of the theory, but decisively depends on the political and ideological position of the same social groups which have significant impact on the shape of introduced systemic solutions.

The studies the book comprises are presented in three parts, arranged in a logical order. They are preceded by an introduction, in which scientific

Barbara Polszakiewicz, Nicolaus Copernicus University, Faculty of Economic Sciences and Management, Department of Economics, ul. Gagarina 13A, 87-100 Torun, Poland, phone: +48 5661146 22, e-mail: bpolszak@econ.umk.pl. 
editors of the book focus on explaining why it is appropriate to deal with "... ideas (ordoliberalism) and the concepts of economic policies (social market economy) which have arose and developed many decades ago".

The first part entitled Ordoliberalism as a theoretical basis for shaping the socio-economic system, opens with two articles of a very synthetic character and thus fundamental to the nature of work The first one, written by Piotr Pysz, justifies why ordoliberalism may provide a basis for shaping economic policy in the twenty-first century. In the article titled Systemic dysfunctions and dilemmas, Elżbieta Mączyńska competently contributes to the discussion on the construction of proper model of the economic system matching modern conditions.

The authors of subsequent articles deal with more detailed, yet important phenomena. These include such significant issues as the search of normative basis for anti-crisis economic policy strategy (Grzegorz Szulczewski), or an explanation of why in the social market economy the synthesis of "scientific approach" and "engineering" can be noted. Wojciech Giza starts his paper with the definition of the above approaches introduced by G. Mankiw'a in 2006. The author tries to analyse the approach characteristic of the representatives of the social market economy in categories proposed by Mankiw'a. The analysis led to the conclusion that in the case of a social market economy, based on the ideas of German ordoliberalists and the experiences of L. Erhard era, the dichotomy between a scientist and an engineer approach does not occur. Two remaining articles included in the first part of the work regard the concept of the social market economy in terms proposed by Alfred-MüllerArmak and the development of real economic systems within social market economy. Sylke Behrens attempts to find an answer to the question: How did it happen that the social market economy transformed from the original concept of market economy oriented towards competitiveness into the distributional market economy with a high state involvement? Furthermore, she asks whether it is possible to reverse this process towards a social market economy in line with its institutional governance?

The second part of the book is titled: Social market economy - a contemporary dimension. It opens with an article by Ludwig Erhard personal referee, Horst Friedrich Wünsche entitled Timeliness concept of Ludwig Erhard social market economy. The article starts with a fundamental question: Is the social market economy a guideline to be followed or a relic of the past? The answer to this question is clearly highlighted in the title of the closing paragraph, which includes a conclusion suggesting that it is worth attempting to return to Ludwig Erhard social market economy. 
Two further articles have also been devoted to the creator of the concept of the social market economy in its clash with contemporary times. Maciej Miszewski very carefully tries to track down the feature of validity in the renowned Ludwig Erhard work: Prosperity for all. Eugene Gostomski, in turn, focuses on the analysis of Ludwig Erhard attitude towards economic integration in Europe. It is worth noting that in the closing $6^{\text {th }}$ paragraph, the author confronts the economic and political ideas of Ludwig Erhard to recent problems related to the debt crisis in the euro zone. Aloysius Czech in the next article of the the book deals with a lighter problem, but he it in a very interesting way. This issue is the influence of his first academic master Wiliam Rieger on Ludwig Erhard, while he was studying as an undergraduate in Nuremberg. The second part of the book closes with the article by Professor Peter Hampe from the Technische Universität Dresden, in which the attempt was made to synthetically confront the recent financial crisis with the basic principles of social market economy.

The third part of the book entitled Shaping the socio-economic system in selected countries, starts with Michał Moszyński article devoted to systemic transformation of East Germany, from the perspective of the so-called Ludwig Erhard "economic miracle". This angle has forced the author to pose basic questions about the sources of very high economic growth of the Federal Republic of Germany in the days of Ludwig Erhard and the reasons for meager results of the economy of eastern federal states so far, following reunification.

In the following two articles, the problems of socio-economic development of the $c$ the European Union member states are analysed. The first one (Ewa Kudlińska-Sadłocha) focuses on the confrontation of strategy for sustainable development set out in the basic EU documents and reality. The second one (Gerhard Schüsselbauer) deals with the problems of socio-economic development of the so-called new EU member states. Particular importance in the formation of future scenarios is attributed to the fact that this development takes place in an era of rising sovereign debt. The article finishes off with an interesting juxtaposition of five possible scenarios for the future. These include "Titanic" scenario, as well as "The internal de luxe market".

Although two last articles are of less general, they are very interesting, especially for Polish readers. The first one by Roland Schariffa concerns the welfare state in Kazakhstan, while the second (Justin Schulz) concerns Polish economic transformation from ordoliberalism perspective, with a special attention paid to the relations of ownership with the economic development.

The views of economic theorists about the desired economic model, its characteristics and mechanisms have been and continue to be subject to more 
or less radical changes. The functioning systems are judged to be, at best, only partially corresponding to the ideas of an optimal model. Two contemporary business models: American (also called Anglo-Saxon) and German are certainly models, drawing the attention of both economic theorists and practitioners carrying out certain versions of economic policy. It should be immediately emphasized that despite its many unquestionable successes, the German model of a social market economy remains in the shadow of the American model. In this situation, the emergence of a book of a series of articles whose authors are trying to figure out how far the proposals of ordoliberalism theorists retain their validity when confronted with the challenges of modern times, is to be welcomed and recommend for both students of economic faculties and demiurges of Polish economic policy. 